\title{
Being on a List: Class and Gender in the Registries of Jewish Life in Jerusalem, 1840-1900
}

\author{
Yali Hashash
}

This chapter explores the position of women and the poor within Jerusalem's Jewish communities ${ }^{1}$ by tracing the presence of these marginalized groups in registries created by contesting religious and administrative institutions in Jerusalem around the same time: the Sephardic Kolel and the English Mission Hospital (EMH). The Sephardic community of Jerusalem was reestablished in 1726, after decades of demographic decline. In 1841, the Ottoman Empire, in accordance with the centralistic tendencies of Ottoman reforms, appointed a haham bashi (an Ottoman government-appointed chief rabbi) as a senior official of the Jewish community and its representative to the regime. By the 1850s, the community numbered between six and eight thousand individuals. Of those, Ashkenazi Jews constituted about a third. The Ashkenazi population grew until they were able, in the 1860 s, to depart from the Sephardic Kolel to establish several small kolels of their own according to origin or specific religious practices. The Maghreb Jews similarly worked to establish their own kolel, and other ethnic groups such as Persian and Georgian Jews did the same. Nevertheless, the weakened Sephardic Kolel remained the largest and most stable kolel throughout the century, functioning as the sole representative of Jerusalem's Jews to the Ottoman authorities. ${ }^{2}$ Each kolel had its own traditional charitable associations and practices. Those were challenged from the 1840 s onwards, when modern philanthropic institutions were introduced.

Since the 1840s, different institutions have worked to establish modern philanthropic structures, mainly hospitals and schools, for Jewish communities in Jerusalem. These offered local, personal, and sectarian applications of modern state-like biopolitical power, and it was in this context that modern registries

1 For the use of the term "communities," see Yair Wallach, "Rethinking the Yishuv: LateOttoman Palestine's Jewish Communities Revisited," Journal of Modern Jewish Studies 16, no. 2 (2017).

2 Yehoshua Ben-Arieh, 'Ir bi-R'i Tekufah-Yerushalayim ba-Me'a ha-Tesha-'Esre, ha-Ir ha-'Atika [A city reflected in its times: Jerusalem in the nineteenth century: The Old City] (Jerusalem: Yad Ben-Zvi Institute, 1977), 303-36.

(C) YALI HASHASH, 2018 | DOI:10.1163/9789004375741_029

This is an open access chapter distributed under the terms of the prevailing CC-BY-NC-ND License at the time of publication. 
were introduced. The $\mathrm{EMH}$, established in 1844 , by the London Society for Promoting Christianity Amongst the Jews, also known as the London Jewish Society (LJS), was the first of such institutions. The Емн had a regulative aspect, given that it brought the Jewish body under the auspices of scientific scrutiny. At the same time, it offered life-sustaining services. Montefiore censuses mentioned in this chapter relate to the regulation of population, whereas the account book management reveals a growing awareness of the need to sustain the Jewish population under the kolel's responsibility.

\section{Historicizing Lists}

Lists and tables belong to a particular genre of writing, used to record inventories even before the invention of the alphabet. ${ }^{3}$ Though they may seem impersonal, lists often convey an intimate reality of the way individuals were classified and made into subjects, particularly in the nineteenth century. ${ }^{4}$ Michel Foucault's concept of biopolitics may be useful in studying practices of list-making or registration. Foucault's notion refers to a new technology of governing populations that gathered momentum in the eighteenth century, enabling the creation of modern nation-states. This new power is distinguished from earlier modes of governance. Biopolitics are not concerned with tools of pure punitive power or a power of deduction involving the taking of lives or property. Rather, the role of power in biopolitics is to sustain life, or better yet, to encourage it. Through modern medicine, road security, education, and the like, biopolitics has penetrated and regulated every aspect of the life of the citizen. Modern statistical lists, an important biopolitical practice, enable individuals to receive governmental services all the while registering them as potential objects of knowledge and, therefore, discipline and regulation. Lists follow a variety of rules of exclusion or inclusion. In History of Madness, ${ }^{5}$ Foucault explored the idea of social exclusion through the historicization of the concept of madness. Foucault was able to historicize and denaturalize the social exclusion of those who were deemed mad; showing that madness is not only a medical construct but also a legal, cultural, and political one. In the

3 Jack Goody, The Domestication of the Savage Mind (Cambridge: Cambridge University Press, 1977), 74-111.

4 Michel Foucault, The History of Sexuality, vol. 1, trans. Robert Hurley (New York: Vintage, 1990), 135-59.

5 Michel Foucault, History of Madness, ed. Jean Khalifa, trans. Jonathan Murphy and Jean Khalifa (London: Routledge, 2013). 
wake of Foucault, social critical theorists have used the idea of social exclusion to decipher the social constructions of societies and institutions and the rules by which they include or exclude certain individuals. Archival work in particular is important to this methodology as it allows scholars to unearth the ideology, philosophy, and politics behind these regimes of inclusion and exclusion. ${ }^{6}$

Jewish communities in Jerusalem were already familiar with state and communal registration practices of the countries from which they had immigrated. While some practices were considered beneficial - either to an individual or to the congregation - others were seen as harmful. The collective memory of the past homelands would have included modern population control mechanisms designed to allow the regulation of ethnically and religiously heterogeneous populations. The Jews of Jerusalem also would have been able to recall ways of evading or complying with those new demographical techniques. In eastern Europe in the nineteenth century, expedited state centralization worked to incorporate thousands of small Jewish corporative communities into the general polity. As part of that effort, states legislated compulsory metrical registries of births, deaths, and marriages. Multiethnic empires such Austro-Hungary or Russia sought administrative reforms that would break corporate organizations and create a more direct regulatory relationship between the individual citizen and the throne. Such reforms met with reluctance and noncooperation on the side of the Jews and other minorities of those empires. In 1804, for example, the Russian Empire demanded that Jews acquire surnames, a step that "signaled the beginning of a gradual transformation of Russian Jewry into a 'legible' people - from an inclusive corporate body to a component of the population that could be governed, categorized, and identified unambiguously through statistical publications and administrative reports." ${ }^{7}$

Like peasants and other minorities, Russian Jewish congregations were reluctant to practice metrical registrations out of fear of expulsion from cities, taxes, or conscription. Archivists of provincial towns and villages were happy to help local people erase files that could be used in their disfavor should the regime gain access to them. However, the incapacity of the regime to allocate professional manpower to the new administrative tasks allowed locals to slow

6 Michael A. Peters and Tina A. C. Besley, "Social Exclusion/Inclusion: Foucault's Analytics of Exclusion, the Political Ecology of Social Inclusion and the Legitimation of Inclusive Education," Open Review of Educational Research 1, no. 1 (2014).

7 Eugene M. Avrutin, "The Politics of Jewish Legibility: Documentation Practices and Reform during the Reign of Nicholas I," Jewish Social Studies 11, no. 2 (2005): 137. 
down the penetration of state biopolitical power into the intimate practices of daily life. ${ }^{8}$

The Ottoman Empire experienced similar processes: Sultan Mahmud II (1808-39) initiated a census to allow the creation of a new army after destroying the Janissary Corps in 1826 . The census was to allow an efficient conscription of male Muslims between the ages of 16 and 40, but its other purpose was to collect cizye taxes from Christians and Jews. Like in the Russian Empire, administrative mechanisms had not yet been developed. As a result, the sultan had to lean on the religious hierarchy to perform the actual registration, which was executed partially and poorly. Whether to evade conscription, taxes, or excess government control, the population at large cooperated little with the sultan's desire to enumerate his subjects. Females were not counted at all. ${ }^{9}$

By the last quarter of the nineteenth century, however, censuses were no longer being used solely as a means of deduction - taxes and conscription but were also utilized to sustain the population through public welfare, transportation, health, and other functions that had until that point been the responsibility of the communal organization of the sultan's subjects. As a result, a far more comprehensive and effective census system than the Empire had previously seen emerged during the last decades of its existence. The new census began between 1881 and 1893, and included females for the first time. Individuals were now required to carry identity cards with them when traveling or dealing with government departments, a prerequisite that elevated levels of population cooperation. ${ }^{10}$ It also meant being listed for taxes or conscription. Thus, the subjugation process - being recognized as eligible for citizenry benefits such as travel or a business license - entailed the elements of subjectification to the deductive power of the state.

This chapter considers two registries: one created by the Sephardic Kolel and another produced by the EMH. The account book of the Sephardic Kolel $\left(185^{-}-80\right)$ sheds new light on changing attitudes towards poverty and communal responsibility. The medical diaries of the Емн (1842-99) reveal that poor Jewish women were instrumental in using and shaping the new public spheres established by the mission to target the Jewish poor. Other sources such as the Montefiore censuses and their attached petitions are used to further elaborate

\footnotetext{
$8 \quad$ Ibid., 139 .

9 Stanford J. Shaw, "The Ottoman Census System and Population, 1831-1914," International Journal of Middle East Studies 9, no. 3 (1978).

10 Musa Şaşmaz, "The Ottoman Censuses and the Registration Systems in the Nineteenth and Early Twentieth Centuries," Osmanlı Tarihi Araştırma ve Uygulama Merkezi Dergisi OTAM 6 (1995).
} 
on the idea of lists and the ideological and administrative principles that determine their exclusion and inclusion regimes.

\section{When Registers become Archives}

The Department of Manuscripts and the Institute of Microfilmed Hebrew Manuscripts in the National Library of Israel (NLI) ${ }^{11}$ holds a large number of documents, the originals of which either belong to the NLI or to other collections and archives around the world. The NLI website states that the department "has undertaken to collect copies of all extant Hebrew manuscripts, whether privately owned or housed in public collections, from all over the world, by means of the Institute's seventy-six thousand reels of microfilm and thousands of scanned digital images." ${ }^{12}$ The NLI holds the original account book analyzed here as well as its microfilmed copy. Among its microfilmed reels are the Montefiore censuses and some attached petitions.

Jerusalem's archives hold a rich variety of account books belonging to merchants, institutions, and congregations. A joint research effort such as Open Jerusalem has the potential to create a detailed and versatile economic history of the city. As economic relations often crossed sectarian lines, this kind of effort can tell the city's social, political, and economic history in unprecedented detail. Account books are a source that requires time to analyze, as they usually need to be deciphered and interpreted using multiple expertise. Such analyses may benefit significantly from a team effort. Some of the chapters in this volume point to available economic sources: Stéphane Ancel mentions financial sources of the Ethiopian Church, some of which may be accounting ledgers, and Angelos Dalachanis and Agamemnon Tselikas report on income and expense registers of the Greek Orthodox Patriarchate of Jerusalem from the mid-nineteenth to mid-twentieth centuries. ${ }^{13}$

11 The NLI defines itself as the national library of the state of Israel and as the national library of the Jewish people. As such it aims to collect all material published in Israel or about Israel, as well as "the cultural treasures of Israel and of Jewish heritage." See http:// www.nli-education-uk.org.

12 http://web.nli.org.il/sites/NLI/English/collections/manuscripts/Pages/default.aspx.

13 See Stéphane Ancel's chapter, "The Ethiopian Orthodox Community in Jerusalem: New Archives and Perspectives on Daily Life and Social Networks, 1840-1940," and Angelos Dalachanis and Agamemnon Tselikas' chapter, "The Brotherhood, the City and the Land: Patriarchal Archives and Scales of Analysis of the Greek Orthodox Jerusalem in the Late Ottoman and Mandate periods," in this volume. 
The account book presented here makes a particularly good historical source for several reasons. First, changes discovered in an account book may reflect dramatic changes in community life. Historians of bookkeeping claim that throughout history, bookkeeping was an adaptive process that changed in accordance with conditions of time and place. Despite its adaptive tendencies, bookkeeping shows a certain dimension of stability because changes do not occur without significant reason. ${ }^{14}$ As such, we are able to use account books to examine change in the community. Second, the specific book discussed in this chapter was written in a manner that did not enable efficient external auditing. The ongoing reports were registered adjacently to their execution and do not rely on memory over time, which grants the book a high level of reliability. Third, reading and deciphering the $75^{\circ}$ pages of the account book is slow work. The nature of the work required to analyze such a source moderates potential bias in interpreting its findings.

In recent years, the Conrad Schick Library and Archive in Christ Church in Jerusalem have been cataloging and digitizing materials pertaining to the $\mathrm{LJS}^{.15}$ As librarians explained to me during my visits there in 2016, it is an ongoing process, and many documents, including maps, sketches, and letters, are yet to be revealed to researchers. Many items were transferred from the Oxford Bodleian Library, including the Medical Diaries of the EMH. Jerusalem's archives have rich materials about the philanthropic enterprises of the nineteenth and early twentieth centuries, and in particular medical philanthropies such as the French Catholic Hospital, built in 1851, and the Greek Hospital, built in $1871 .^{16}$

\section{The Sephardic Kolel Account Book: Between Inclusion and Exclusion}

New accounting history has developed as a branch of social and economic history since the 1970s, and was influenced by Foucault's analysis of power and bureaucratic knowledge. ${ }^{17}$ Research in that field has yielded some important

\footnotetext{
14 John R. Edwards, A History of Financial Accounting (London: Routledge, 1989), 14.

15 http://cmjisrae.w16.wh-2.com/CMJ-Ministries/Heritage-Centers/Conrad-Schick-Library.

16 For a survey of these institutions see Norbert Schwake, "Hospitals and European Colonial Policies in the 19th and Early 2oth Centuries," in Health and Disease in the Holy Land, ed. Manfred Waserman and Samuel S. Kottek (Lewiston: Edwin Mellen, 1996).

17 Christopher J. Napier, "Accounts of Change: 30 Years of Historical Accounting Research," Accounting, Organizations and Society 31, no. 4 (2006).
} 
insights, not least of which is the understanding that methods of accounting are never a transparent tool of adding and subtracting economic data, but a form relating content. Revealing the method of accounting allows us a glimpse into the ideological structure of the organization studied. This section relates to one specific financial source: the Sephardic Kolel account book (1851-80) containing the logs of the kolel incomes and expenses in those years as well as some financial contracts. It is stored at the Israel State Archives, and except for a few pages, it was first studied in my $\mathrm{PhD}$ dissertation. ${ }^{18}$ The $75^{\circ}$ manuscript pages include handwritten notes in Hebrew, combined with words in Aramaic, Turkish, Ladino, and Arabic, all in Hebrew characters.

The Sephardic Kolel account book is doubly paginated - one count is for pages and the other for columns, but occasionally there is a gap in page numbers and they do not correspond to column numbers. In addition to entries for incomes and expenses, the book contains three contracts signed throughout the years as well as several receipts for the cancellation of bonds. The income pages contain entries of income from emissaries, taxes, loans, and sale or lease of assets. The expense pages log items such as salaries, maintenance expenses, orphan fund expenses, accommodation of foreign dignitaries, charity, payment to scholars, payment of debts (principal and interest), taxes and bribes to officials. These items are not later summed, and there is no general account of annual income from tax or other sources, nor is there a general balance of annual expenses for salaries or debt repayment. Some of the donations by philanthropists such as Rothschild and Montefiore to particular groups in the community or for the purpose of establishing institutes were not recorded in the ledger at all. The account book therefore did not provide kolel management with a coherent picture of the community's overall financial status. An annual balance appears only once towards the end of the documentation. The lack of annual balances is an oddity that raises an important research question: if an annual accurate financial picture was not a purpose of the bookkeeping, then what was?

18 Pages from the first half of 1850 and from the month of Heshvan in 1854 are mentioned in Israel Bartal's "Berurim be-Shuley Tazkir Kolel ha-Sefaradim bi-Rushalayim Mi-Shenat Tartav" [Some queries regarding the 1885 memo of the Sephardic Kolel in Jerusalem], Zion 43 (1978). Yali Hashash, "Shinuy Gishot Klape 'Oni ba-Kehila ha-Sefaradit be-Yerushalayim, 1841-1880" [Changing attitudes toward poverty in the Sephardic community of Jerusalem, 1841-1880] (PhD diss., University of Haifa, 2011); Hashash, "Iske Halva'ot: Nihul Kaspe ha- Kehila ha-Sefaradit bi-Rushalayim ba-Me'ot ha-Shemone-'Esre ve-ha-Tesha'-Esre le-'Or Mismakhim Hadashim" [Loan business: the management of the Sephardic community's coffers in Jerusalem in the eighteenth and nineteenth centuries in the light of new documents], Zion 78, no. 4 (2013). 
In order to answer this question, we must first specify the method of bookkeeping kept in the ledger. It seems that the account book was maintained in the style of "income-expense" customary from Roman times and used around the world throughout history. This system includes several forms of documentation based on single entry, meaning one registry for each income or expense item, covering the flux of resources over time, without discriminating profit from income, or between various transaction types. This type of account has two primary goals: first, to enable the account manager to balance incomes and expenses, and second, to enable supervision of resource collection and allocation and of those entrusted with finances. In an organization such as the Sephardic community, donors may have wanted to know how their donations were allocated and whether the kolel managers were carrying out their duties honestly.

Alongside this single-entry system, a double-entry system evolved. Doubleentry bookkeeping is based on recording any quantitative activity in a system where at least one party is debited, and another credited. Recording a debit amount to one account and an equal credit amount to another account results in total debits being equal to total credits for all accounts in the general ledger. If the accounting entries are recorded without error, the aggregate balance of all accounts having positive balances will be equal to the aggregate balance of all accounts having negative balances. This method came into widespread use only in the mid-nineteenth century as a result of an increase in modern business initiatives and the separation between ownership and management of business. Changes in bookkeeping in the middle of the century expressed the change in its role. From a means of assessing the ability of a certain entity to repay or properly manage a deposit, bookkeeping became a source of information for making decisions regarding resource allocation and a basis for investment and profit.

Unlike double-entry bookkeeping, single-entry bookkeeping does not measure profit and does not evaluate performance, as incomes were generally regular, and expenses inevitable. Under these circumstances, an approach that was primarily supervisory was entirely sufficient. Therefore, smaller communities such as church congregations, monasteries, and other religious communities continued to use single-entry bookkeeping. ${ }^{19}$ Account management in

19 Edwards, A History of Financial Accounting, chaps. 4 and 5. In the 1860s, the Ottoman Empire began using double entry bookkeeping. The importance given to learning new methods of accounting as part of reform and social change is evident by the fact the Butrus al-Bustani (1819-93), one of the prominent Nahda scholars, published a guidebook 
the Jerusalem Sephardic community was therefore similar to the management of smaller religious communities, and its primary role was to balance incomes and expenses and prove to donors that the community's finance managers were not embezzling money.

The different entries in the account books from the eighteenth and nineteenth centuries show that the Sephardic community had economic ties with non-Jews in Jerusalem. ${ }^{20}$ Loans with high interest were taken from influential Armenians, Muslims, and Christians, just as they were taken from the elite members of the community. The kolel's coffer served as a high interest investment for a close circle of beneficiaries, among whom were non-Jewish local elite. This practice of loaning caused recurring financial crises. ${ }^{21}$ Indeed, the account book exposes the grave financial crisis faced by the kolel in 1853-54.

The book suggests that a general crisis lasted throughout the period the book was kept. The crisis was an evolving challenge, continually requiring varied solutions and diverse coping strategies. The solutions chosen were responses to constraints imposed by the external reality as well as responses to power structures within the community and tensions between differing sociopolitical concepts. These different strategies are reflected in the exclusion and inclusion regimes that governed the ideological and financial structure of the accounting operation. In particular, it uncovers changing attitudes regarding who was eligible to receive communal charity. The unlearned poor, who were almost entirely excluded from communal support until the mid185 os, were deemed eligible during the second half of the century.

\section{The Missionary Registers from the Conrad Schick Library and Archive: A Biopolitical Reading}

One of the items in the Conrad Schick archive are the medical diaries of the EMH by its directors during their tenure: Dr. Macgowan (1842-6o), Dr. Chaplin

on double-entry bookkeeping for merchants, stressing in its introduction that this knowledge had become crucial in order to comply with the new state law. Butrus al-Bustani, Kitab rawdat al-tajir fi mask al-dafatir [The trader's guide to bookkeeping] (Beirut, 1859). I thank Nicole Khiat for bringing this source to my attention.

20 Jacob Barnai, "The Jerusalem Jewish Community, Ottoman Authorities and Arab Population in the Second Half of the Eighteenth Century: A Chapter of Local History," Jewish Political Studies Review 6, no. 34 (1994).

21 Hashash, "Shinuy Gishot Klape” and "Iske Halva’ot." 


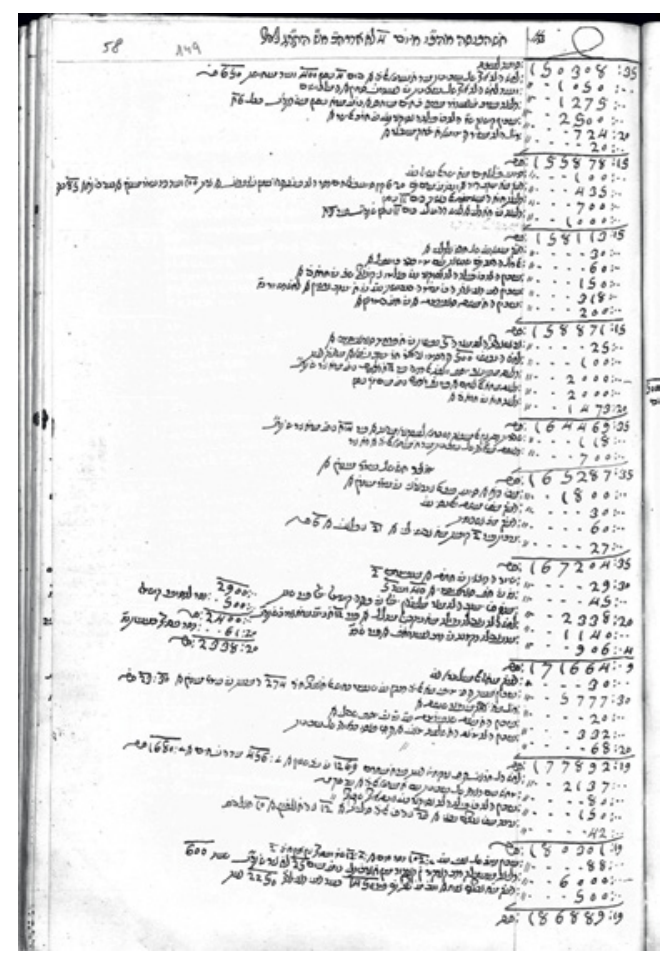

FIGURE 23.1

A page from the Sephardic Kolel account book, 1851-80, income, Adar 5613 (January-February 1853).

(1860-85) and Dr. Wheeler (1885-1909). The diaries' first entries are from early 1842, when the LJs Jerusalem clinic was first opened, and they follow the establishment of the EMH in 1844 by the LJS and the following seven decades.

The material in the medical diaries is of a double nature. Macgowan, who served as a physician in Jerusalem from 1842 to his death in 1860, wrote narrated reports on a regular basis. These were often published in the LJS journal, Jewish Intelligence, and were complemented by statistical data. His successors Chaplin and Wheeler, only wrote statistical reports, that is, tables that registered the number of admissions to the hospital and clinic visits according to gender, healing rates of hospital patients (but not clinic patients), and often the ethnicity of patrons. While many of these tables were published in Jewish Intelligence, the medical diaries offer an ordered sequence and details that were sometimes omitted in the journal. Other documents in the Conrad Schick archive, such as sermons, letters, and the entire volumes of Jewish Intelligence, offer a glimpse into varied aspects of evangelical discourse regarding the Jews. 
Researchers to date have largely depicted the medical establishments that sprung up in Jerusalem from the point of view of philanthropists, doctors, European interests or the local leadership. ${ }^{22}$ These studies brought to light the EMH's vast operation, the opposition it attracted and the competing Jewish initiatives it inspired. Most researchers agree on some basic facts based on contemporary evidence, namely: the hospital offered welfare as well as medical services; ${ }^{23}$ it accommodated the Jewish religious needs of its patients; ${ }^{24}$ there were hardly any proselyting efforts within the hospital compound; rabbinic institutions raised objections of one sort or other; ${ }^{25}$ the presence of the hospital gave rise to modern Jewish medical institutions; ${ }^{26}$ the medical mission was known for its high level of professional and personal service; and finally, despite objections and competition, and apparently due to its high level of professionalism and compassion, Jewish patients kept using its services. Researchers have used the published statistical data as sources of fact, though they were aware that the numbers were not necessarily accurate. Contemporary observers and current researchers often remain skeptical about the reliability of the numbers the EMH published.

22 Norbert Schwake, “Hospitals”; Marcel Chahrour, “A 'Civilizing Mission'? Austrian Medicine and the Reform of Medical Structures in the Ottoman Empire, 1838-1850," Studies in History and Philosophy of Science of Biological and Biomedical Sciences 38, no. 4 (2007); Shifra Swarts, "Meshihiyut ve-Politika be-Hakamat Mosdot ha-Refu'a ha-Yehudiyim ha-Rishonim bi-Rushalayim ba-Me'ah ha-19" [Messianisme and politics in the establishment of the first Jewish medical institutions in Jerusalem in the 19th century], in Refu'ah bi-Rushalayim le-Doroteha [Medicine in Jerusalem throughout the generations], ed. Efraim Lev et al. (Tel Aviv: Erets, 1999).

23 Yaron Perry, "Medical Treatment as a Missionary Instrument and Its Social Consequences: Aspects of the Work by the London Jews Society in Palestine up to 1914," in The Social Dimension of Christian Missions in the Middle East: Historical Studies of the 19th and 2oth Centuries, ed. Norbert Friedrich, Uwe Kaminsky, and Roland Löffler (Stuttgart: Franz Steiner, 2010), 149.

24 Margalit Shilo, Princess or Prisoner? Jewish Women in Jerusalem, 1840-1914, trans. David Louvish (Waltham: Brandeis University Press, 2005), 204.

25 Yaron Perry and Efraim Lev, Modern Medicine in the Holy Land (London: I. B. Tauris, 2007), 36-38; Ruth Kark and Shlomit Langboim, "Missions and Identity Formation among Indigenous Populations in Palestine:The Case of the Jewish Population," in Friedrich et al., The Social Dimension of Christian Missions, 112-15; Morgenstern, like Kark and Langboim, points to the measure of cooperation between the Perushim Jews and the Protestant mission. See Arye Morgenstern, Ha-Shiva li-Rushalayim [The return to Jerusalem] (Jerusalem: Shalem, 2007), 352-55.

Schwake, "Hospitals." 
Taking these findings of previous research as a basis, I take a more analytical approach to the statistical reports to discern patterns over the years. Even if numbers were inflated, recurring patterns might offer some insight into the demographics of the population that received medical care in the Емн. Furthermore, the availability of similar reports from other institutions allows us to widen our understanding of the different ways in which the Jewish population in Jerusalem accepted these institutions. My findings show that over the decades more women than men frequented the EMH (clinic and hospital), and that compared with the Rothschild Hospital, this trend seems to be characteristic. The Rothschild Hospital usually admitted more men than women. ${ }^{27}$

Statistical data from the EMH (see table 23.1) shows that more women than men were hospitalized despite the number of beds being equal in the men's and women's wards. Women continued to constitute the majority of hospitalized patients although their ratio was slowly decreasing, finally stabilizing around 55 percent. It further shows that in the outpatient clinic women consistently made up two-thirds of the patients, making the presence of women in the building, whether hospitalized or outpatients, central.

TABLE 23.1 Average clinic visits to the English Mission Hospital, 1862-80, by gender ${ }^{\mathrm{a}}$

\begin{tabular}{llllll}
\hline Year & Women & Men & Total & Women (\%) & Men (\%) \\
\hline $1862-65$ & 3,310 & 1,756 & 5,066 & 65 & 35 \\
$1866-70$ & 5,291 & 2,815 & 8,106 & 65 & 35 \\
$1871-75$ & 4,902 & 2,687 & 7,589 & 65 & 35 \\
$1876-80$ & 4,519 & 2,597 & 7,116 & 63 & 37 \\
\hline
\end{tabular}

a The medical journal does not provide distribution by gender for the clinic visits of 1861 . SOURCE: MEDICAL DIARIES OF THE ENGLISH MISSION HOSPITAL.

27 See Yali Hashash, "Gender, Religion and Secularism in the English Mission Hospital of Jerusalem, 1844-1880," Journal of Levantine Studies 7, no. 1 (2017). 
During the 186os, different quarterly reports of the Rothschild hospital were published in different Jewish newspapers. They appear to indicate that more men than women were admitted to the Rothschild Hospital. ${ }^{28}$ Table 23.2 shows that during the six consecutive years reported in the Jewish newspapers, an average of 46.75 percent of women were hospitalized, compared to an average of 53 percent during the same time in the Емн. The gap in actual numbers reported can be explained by the fact that the EMH had 24 beds and the Rothschild Hospital had only $18 .{ }^{29}$ It can thus be argued that the EMH was more of a feminine public space than its counterpart.

TABLE 23.2 Hospitalization at the Rothschild Hospital, 1870-76, by gender

\begin{tabular}{|c|c|c|c|c|c|c|}
\hline $\begin{array}{l}\text { Jewish } \\
\text { year }\end{array}$ & $\mathbf{A D}$ & Women & Men & Women $(\%)$ & $\operatorname{Men}(\%)$ & Total \\
\hline $5^{6} 31$ & $\begin{array}{l}\text { September } 26,1870-\text { September } \\
16,1871\end{array}$ & 192 & 199 & 49.1 & 50.9 & 391 \\
\hline 5632 & $\begin{array}{l}\text { September } 17,1871 \text {-October } 2 \text {, } \\
1872\end{array}$ & 207 & 243 & 46 & 54 & $45^{\circ}$ \\
\hline $5^{6} 33$ & $\begin{array}{l}\text { October } 3,1872-\text { September } 22 \text {, } \\
1873\end{array}$ & 216 & 244 & 47 & 53 & 460 \\
\hline $5^{6} 34$ & $\begin{array}{l}\text { September } 23,1873 \text {-September } \\
12,1874\end{array}$ & 161 & 198 & 44.9 & 55.1 & 359 \\
\hline 5635 & $\begin{array}{l}\text { September } 13,1874-\text { September } \\
20,1875\end{array}$ & 161 & 183 & 46.8 & 53.2 & 344 \\
\hline 5636 & $\begin{array}{l}\text { September } 21,1875^{-S e p t e m b e r} \\
19,1876\end{array}$ & 191 & 220 & 46.5 & $53 \cdot 5$ & 411 \\
\hline
\end{tabular}

SOURCES: FOR 5631, HAVATSELET, OCTOBER 27, 1871; 5632,JEWISH CHRONICLE, DECEMBER 5, 1873; 5633, HAVATSELET, NOVEMBER 28, 1873, 5634, HAVATSELET, DECEMBER 4, 1874; 5635, HAVATSELET, OCTOBER 29, 1875; 5636, HAVATSELET, DECEMBER 7, 1876.

28 For reports where more men than women are documented as hospitalized patients see:Jewish Chronicle, January 4, 1861; Ha-Melits, March 27, 1862; Ha-Magid, July 26, 1865; Ha-Magid, February 7, 1866; Ha-Magid, July 24, 1867; Ha-Magid, May 6, 1868; Ha-Magid, May 11, 1870. For quarterly reports that document more hospitalized women, see Ha-Levanon, July 9, 1863; Univers Israelite, October 1864; Ha-Magid, September 9, 1868.

Hashash, "Shinuy Gishot Klape," 189. 
These findings allow old evidence to be reexamined and interpreted in a new light. For example, we can now look for a connection between women's partiality to the Емн and attitudes towards women in the Jerusalem Evangelical mission. The special place Judaism had within the British colonial outlook informed the mission's attitude towards the Jews in Jerusalem. The narrative reports for the city as well as the different sermons and other documents found in the Conrad Schick archive, are a good resource for examining the specific interreligion relationship that was being formed in the city during the nineteenth century.

The EMH used modern mechanisms of population management in the sense that people who were treated as outpatients or inpatients were registered and classified. Men were more reluctant than women to be on these lists, supposedly because of the way it reflected on them as Jewish men. The EMH nevertheless remained extremely popular. Though its published numbers may be exaggerated, contemporary Jewish publicists systematically lamented the hospital's high attendance rates. Other Jerusalem medical institutions built for the Jews from the 1840 os on were also very popular. In looking to them for help and services, Jerusalem's poor encouraged the success of these institutions while availing themselves of different public networks.

The only exclusion mechanism that operated at the EMH was religious the institution only served Jews. The EMH's evangelical modernist ideology was reflected in the hospital's policies. The neglected Jewish women and the poor offered the medical missionaries a chance to exhibit what they believed to be some of their superior attributes - their modern perception of women and their compassionate attitude toward the poor. Recreationist ideas that circulated at the time reinforced the use of the EMH as a haven for new Jewish immigrants while the concept of the conversion of the Jews that would, in turn, allow for Christ's Second Coming stressed the importance of acquainting the Jews with Christian morality as exhibited in medical care. The EмH, like other medical institutions that followed, held "state-like" biopolitical power: it rewarded listed individuals with life-sustaining services. The statistics that made up the Емн registries were used for medical research ${ }^{30}$ and, at times, policy-making. Running the hospital contributed to the self-perception of British evangelicals as the benevolent, worthy alternatives to Muslim rule. Yet the subjectification of the patients - that is, turning them into subjects of care,

30 See for example the medical research of Dr. Thomas Chaplin in Efraim Lev and Yaron Perry, "Dr. Thomas Chaplin, Scientist and Scholar in Nineteenth-century Palestine," Palestine Exploration Quarterly 136, no. 2 (2004). 
putting them on lists of individuals entitled to receive the hospital's services was not accompanied by an immediate concrete act of subjugation.

\section{Being or Not Being on the List}

The state-like modern philanthropy that emerged in Jerusalem's Jewish community during the nineteenth century gave rise to new, more inclusive lists. These innovations directly challenged the principles of exclusion that categorized older lists. This is evident in the registry of female names. Jewish registration was traditionally connected with sacramental duties. Therefore, the birth of a boy was likely to be chronicled upon his circumcision and again at the time of his bar mitzvah ceremony. On the other hand, girls were typically registered for the first time upon marriage. Gila Hadar followed Sephardic female names and concluded that a woman's birth name was not only lacking from most registries, but often was not in use at all: "the personal name of a woman ... had little significance," notes Hadar. "The meaning and existence of a girl was only within the collective Jewish context in her role as woman, mother, and widow. After her marriage a woman ... was known as the wife of or the widow of someone."31

In the nineteenth century, the position of women in the Jewish communities of Jerusalem was determined by the community's conception of its calling: the city's rabbis saw the Jews of Erets Israel and particularly of Jerusalem as the center of the traditional rabbinic world and, therefore, as personifying the state of exile. ${ }^{32}$ The ensuing distinction between the worthy, scholarly poor, and the poor, who were considered a liability for the vocation of the

31 Gila Hadar, "Bienvenida 'Blessed be Her who Comes' and Azebuena 'Does Good Deeds': Name-giving Patterns for Girls and Women in the Judeo-Spanish Diaspora (Salonika, 1492-1943)," in Pleasant are their Names:Jewish Names in the Sephardi Diaspora, ed. Aaron Demsky (Bethesda: University Press of Maryland, 2010), 228.

32 Israel Bartal, Galut ba-'Arets [Exile in the homeland] (Jerusalem: Zionist Library, 1994), 16. As elsewhere in the Ottoman Empire, Sephardic rabbis in Jerusalem saw the exile situation as a metaphor for the general human condition of alienation and the existential sense of homelessness. In this view, exile is a voyage in which a man engages in penance so that he may eventually come home. The sufferings of the Jews in the Land of Israel serve in this worldview as a collective penance for the sins of past and present generations. See Matthias B. Lehmann, Ladino Rabbinic Literature and Ottoman Sephardic Culture (Bloomington: Indiana University Press, 2005), 174. 
community, ${ }^{33}$ informed attitudes toward women, who were excluded from Torah studies. This exclusion did not mean that women felt like outsiders to the community or to its values. They could, and indeed did, gain status insofar as they were able to tie their existence to the scholarly activity of men as wives, mothers, or volunteers in a synagogue or a yeshiva. And yet, pauper letters indicate that many contested their exclusion and worked to be part of the new lists. These letters, some of which can be found in the Central Archive of the Jewish People and the Institute of Microfilmed Hebrew Manuscripts in the National Library in Jerusalem, help to further understand the way that lists shaped people's lives. During the nineteenth century, thousands of pauper letters were sent from Jerusalem to European benefactors, begging for immediate relief from poverty. Most of the letters were written by women. ${ }^{34}$ These letters are often cited as evidence of the suffering endured by the Jewish community in Jerusalem. However, they have rarely been analyzed to reveal the reactions of the poor to the realities of their time.

Pauper letters were written either by individuals or by groups. In the Jerusalem archives, I found three documented collective letters: a collective letter to Montefiore from 1849, a collective letter to the British consul James Finn, from $1854,{ }^{35}$ and another letter to Finn from 1861. According to Finn, this petition was from the representatives of 650 families seeking land for farming. ${ }^{36}$

33 When the eminent Jewish historian Tsvi Gertz published a critical report on the Jewish communities of the four holy cities in Palestine, he focused on the distribution of alms as an expression of social evil. The communities' leadership, he claimed, saw the alms from the diaspora as a God-given right that was distributed to the haves while the have-nots received little, if any, money. Ha-Magid, January 15, 1873. This kind of criticism began to appear in Jewish newspapers in the late 1830s. Yehuda Elkalay argued for the restoration of Jews to Palestine and their productivization as a human-induced Ge'ulah. Further research is needed to establish whether there was actually a dialogue between evangelical restorationists and Elkalay.

34 For a review and discussion of pauper letters, see Shilo, Princess or Prisoner, 183-86. Shilo found most of these letters in the Bibliotheca Rosenthalia at the University of Amsterdam. Others are scattered among different archives, such as the Montefiore Archives at Oxford. For an annotated translation of this letter, see Yali Hashash, "A Petition for Aid: A Sephardi Collective in Jerusalem Appeals to the British Consul (1854)," in Sephardi Lives: A Documentary History, 1700-1950, ed. Julia Phillips Cohen and Sarah Abrevaya Stein (Stanford: Stanford University Press, 2014), 50-52.

36 Arnold Blumberg, A View from Jerusalem, 1849-1858: The Consular Diary of James and Elizabeth Anne Finn (Rutherford: Fairleigh Dickinson University Press, 1980); Ruth Kark, "Millenarism and Agriculture Settlement in the Holy Land in the Nineteenth Century," Journal of Historical Geography 9, no. 1 (1983); Vivian D. Lipman, "Britain and the Holy Land: 1830-1914," Jewish Quarterly 37, no. 4 (1990). 
Several elements are evident in the three letters and in other individual appeals I read. First, the independent collective appeals show a clear fear of community sanctions should kolel officials hear of the private initiative. Next, the letters criticize the leadership's lack of interest in its poor. Gender differences are evident: for example, men's appeals ask for much more substantial aid than women's. Awareness of contemporary ideas of citizenship is also evident from the letters, as is an awareness, on the part of the letter-writers, of the risk that paupers might reflect badly on their community when requesting help. These appeals protest the exclusion of their authors from the traditional, communal list and they create new channels of aid distribution and reception. ${ }^{37}$

Cooperation of the Jewish population in the five censuses conducted by Sir Moses Montefiore $(1839,1849,1855,1866,1875)$ was much better than in the Ottoman government census conducted in the 1880s. By the mid-1870s, the Ottoman government intended to use population registries and censuses as means of public development and not only as a way of recruiting soldiers and collecting taxes. The population at large, however, and the Jewish population in Jerusalem in particular, was still suspicious about revealing exact demographic information to the authorities. Before the census of the 1880 , the congregation heads that were in charge of reporting the number of households to the government had grossly underreported household numbers. Even the new census, conducted by professionals, only counted 7,100 Jews in Jerusalem. In comparison, the earlier Montefiore census of 1866 enumerated 6,650 Jews living in Jerusalem. The 1875 census counted more than ten thousand Jews. ${ }^{38}$ One can see the difference between lists that were considered judiciary and those that were considered to improve the well-being of Jerusalemites. Though not complete, the Montefiore lists seem to have been deemed beneficial, or less deductive, than the government's. Some of the disparity between the censuses may be related to the fact that some of the Jews living in Jerusalem preferred to hold European citizenship. But even then, one may argue that having foreign citizenship was another strategy used by Jews to not have to appear on the Ottoman lists.

37 Thus, for example, one of the letters reads, "May his compassion be upon me to write my name in his nook (pinkas)." Letter from a Sephardic widow to Sir Moses Montefiore, Jerusalem, 1849, Institute of Microfilmed Hebrew Manuscripts, INL: F.6193.

38 Hashash, "Shinuy Gishot Klape," adapted from Montefiore Census 1866, Institute of Microfilmed Hebrew Manuscripts, INL, F.6159. 


\section{Concluding Remarks: Inside Out?}

Two contesting religious and administrative institutions that practiced different inclusion and exclusion regimes created the lists and tables discussed in this chapter. In the 1850s, the lists of the account book of the Sephardic Kolel included a very short list of individuals, Jews and non-Jews, who interacted with the kolel's financial administration. This list exhibited what the kolel management saw as its religious and political obligations: as a minority it needed to pacify the strong non-Jewish families in Jerusalem, and as a studious congregation it needed to support its scholars. During the 1860 s, this attitude gradually shifted to include more of Jerusalem's Jewish poor in the lists of the kolel's beneficiaries. The English Mission Hospital in Jerusalem practiced an inclusive attitude towards Jews, excluding all others. Women in particular recognized the new venues through which they were able to negotiate their economic and medical situation. Pauper letters reveal the extent to which women and the poor were aware of the principles that guided the different lists that worked to enable or block a person's involvement in the urban life of nineteenth-century Jerusalem. The gap between the Ottoman and Montefiore censuses suggests different responses to governmental and charitable lists and registries. 